\title{
MOVING GRAVEL BODY METHOD TO CONTROL DOWNCOAST EROSION
}

\author{
Toshinori Ishikawa ${ }^{1}$, Takaaki $\mathrm{Uda}^{1}$ and Shiho Miyahara ${ }^{2}$
}

\begin{abstract}
The concept of the moving gravel body (MGB) method, in which topographic changes are controlled by beach nourishment using gravel, was introduced, using the contour-line-change model considering changes in grain size. The model was applied to the Fuji coast, assuming that coarse materials were nourished on a straight coast wherein a predominant longshore sand transport develops. The grain size that is effective for the recovery and maintenance of the shoreline and that does not cause further downcoast erosion was $d$, which is 5-10 times larger than that of the original sand, $d_{0}$.
\end{abstract}

Keywords: beach nourishment; longshore sand transport; gravel; shoreline changes; Moving Gravel Body method; Fuji coast

\section{INTRODUCTION}

Beach nourishment using coarse materials has been carried out at several beaches in Japan. This is because coarse materials such as gravel have better stability than the original materials, which are mainly composed of fine sand (Kumada and coworkers, 2009; 2010). In a field experiment on beach nourishment using coarse materials on the Chigasaki coast, the movement of gravel was found to be slower than that of sand, and gravel was selectively deposited on the foreshore (Yoshioka et al., 2008). Also, when gravel is used, shore protection effect can be established with less volume compared with sand. Thus, gravel is considered to be effective for economically maintaining the coast in the long term, although the environmental impact is a concern.

Although a stable beach can be formed on a pocket beach because longshore movement of gravels is confined within a pocket beach, on a coast wherein a predominant longshore sand transport develops, slow movement of gravel may cause erosion immediately downcoast of the protected area. This implies that beach nourishment using gravel is not always effective even though the environmental impact on the shoreline is excluded. Also, a method of selecting the appropriate grain size has not yet been shown. In this study, beach changes after beach nourishment on a coast wherein predominant longshore sand transport develops, were investigated using the monitoring survey data on the Fuji coast. Then, the "Moving Gravel Body (MGB) method" in which topographic changes are controlled by beach nourishment using gravel was proposed, and it was applied to the Fuji coast. In particular, beach changes in cases that materials with grain sizes significantly different from the grain size of the original sand were used for nourishment were studied.

\section{BEACH CHANGES AFTER GRAVEL NOURISHMENT}

The study area is the Fuji coast located in Suruga Bay facing the Pacific Ocean, as shown in Fig. 1. The beach is mainly composed of coarse sand and gravel, the grain size of which ranges between 1 and $10 \mathrm{~mm}$, which were originally supplied from the Fuji River, and the beach slope is as steep as 1/10. Although eastward longshore sand transport of $1.0 \times 10^{5} \mathrm{~m}^{3} / \mathrm{yr}$ had prevailed for a long time on this coast, the south breakwater of Tagonoura Port had been extended by 1961 along with the extension of the Showa Floodway across the shoreline in 1986, resulting in the obstruction of the eastward longshore sand transport and downcoast erosion, as shown in Fig. 2. The shoreline changes downcoast of the floodway between 1977 and 1992 are shown in Fig. 3. The shoreline receded over a distance of $2 \mathrm{~km}$ from the floodway with a maximum shoreline recession of $70 \mathrm{~m}$ because of the exhaustion of longshore sand transport.

As a measure against beach erosion, beach nourishment using coarse materials with the grain size of 50-150 mm (Fig. 4) had been carried out at a rate of $1.0 \times 10^{5} \mathrm{~m}^{3} / \mathrm{yr}$ downcoast of the floodway since 1996. Figure 5 shows the area of nourishment of the beach using coarse materials. The grain size of the nourishment materials was as large as 50-150 times the size of the original materials $d_{0}$.

After the beach nourishment, the shoreline markedly advanced downcoast of the floodway, whereas the shoreline downcoast of the nourishment area gradually retreated over time, as shown in Fig. 6. The resulting changes in longitudinal profile along $X=10.75 \mathrm{~km}$ immediately downcoast of the

\footnotetext{
${ }^{1}$ Public Works Research Center, 1-6-4 Taito, Taito, Tokyo 110-0016, Japan

${ }^{2}$ Coastal Engineering Laboratory Co., Ltd., 1-22-301 Wakaba, Shinjuku, Tokyo 160-0011, Japan
} 
nourishment area between 1977 and 2009 are demonstrated in Fig. 7. Up to 1998, the shoreline gradually receded while forming an upward concave profile between +4 and $-12 \mathrm{~m}$, but another concave profile was formed on the backshore due to erosion by 2009. Figure 8 shows the current beach condition downcoast of the nourishment area. A 2-m-high scarp was formed and the roots of coastal trees were exposed due to erosion.

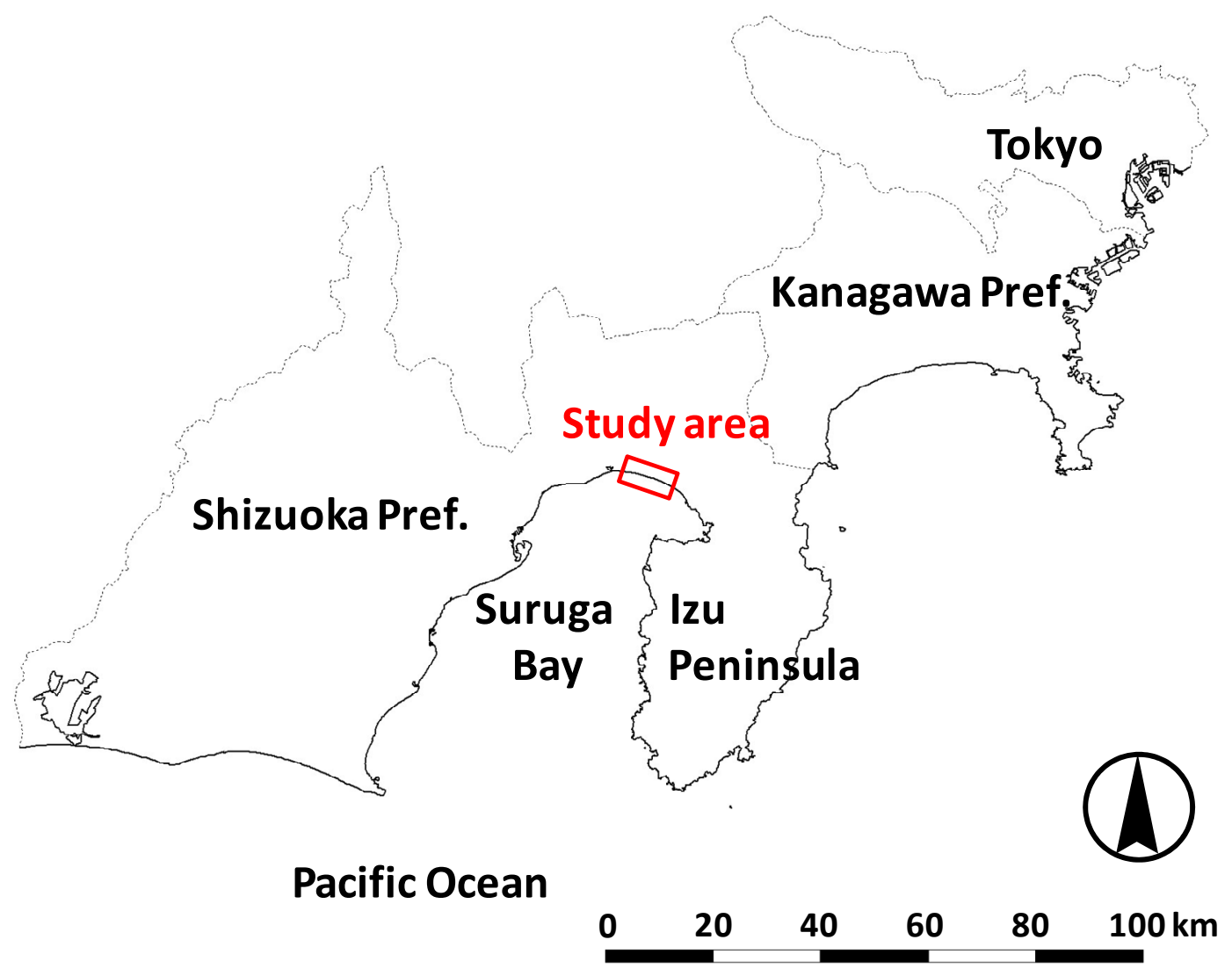

Figure 1. Location of Fuji coast in Suruga Bay.
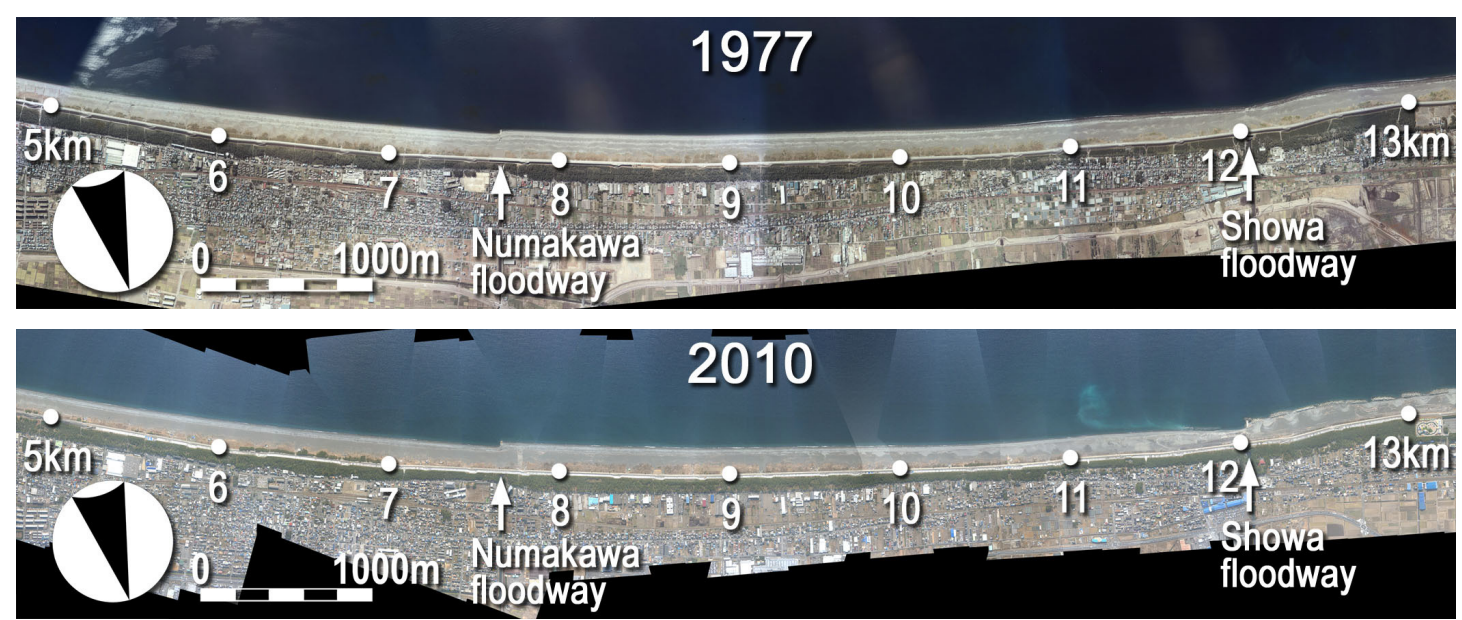

Figure 2. Aerial photographs of Fuji coast taken in 1977 and 2010 (provided by Numazu Office of River and National Highway of the Chubu Regional Bureau, MLIT). 


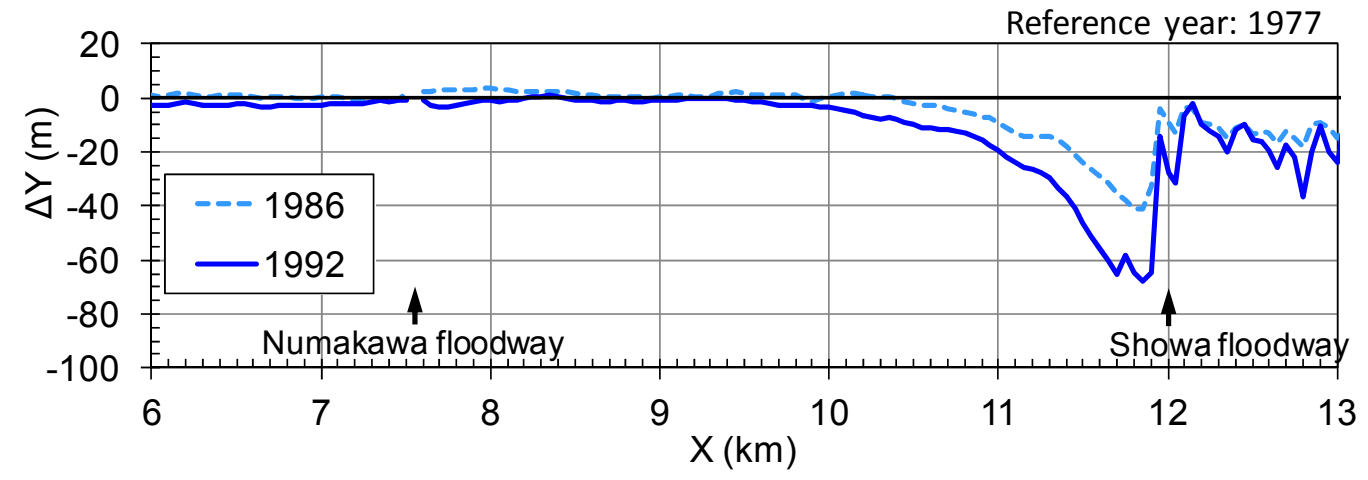

Figure 3. Shoreline changes on Fuji coast between 1977 and 1992 with reference to that in 1977.

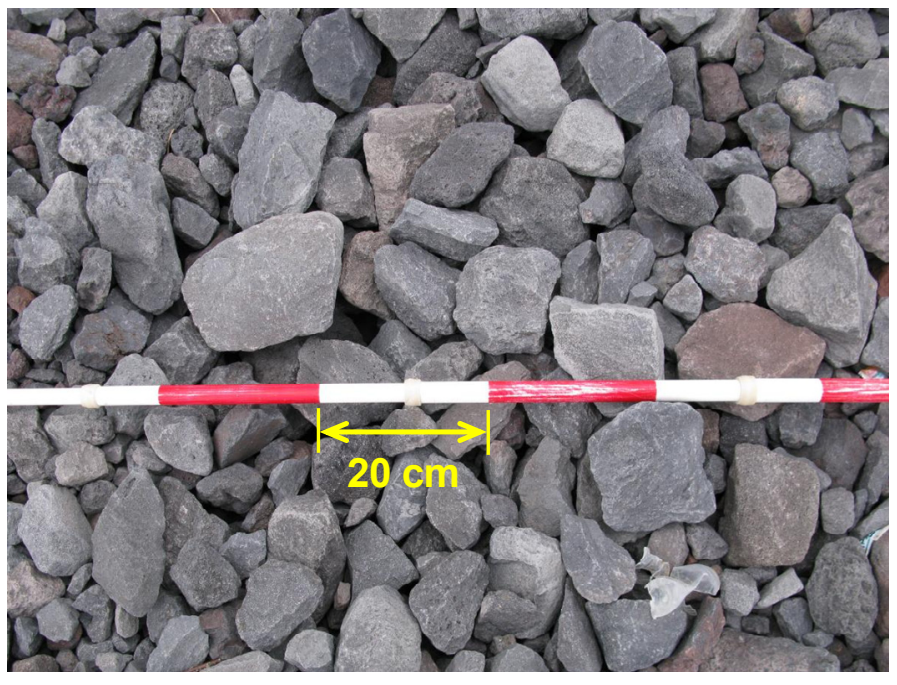

Figure 4. Nourishment materials composed of large gravel.

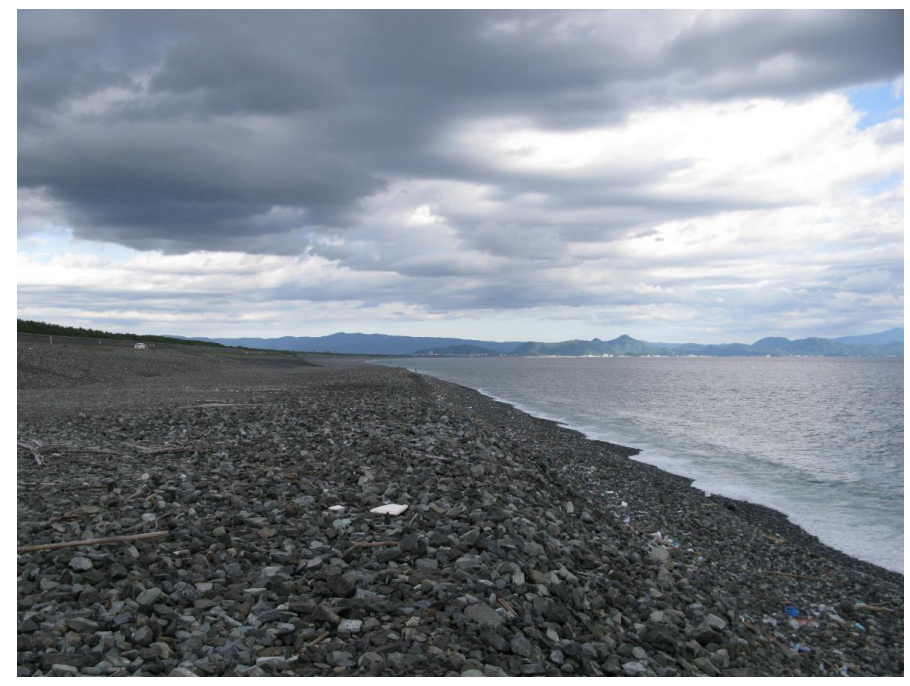

Figure 5. Current condition of nourishment area on Fuji coast. 


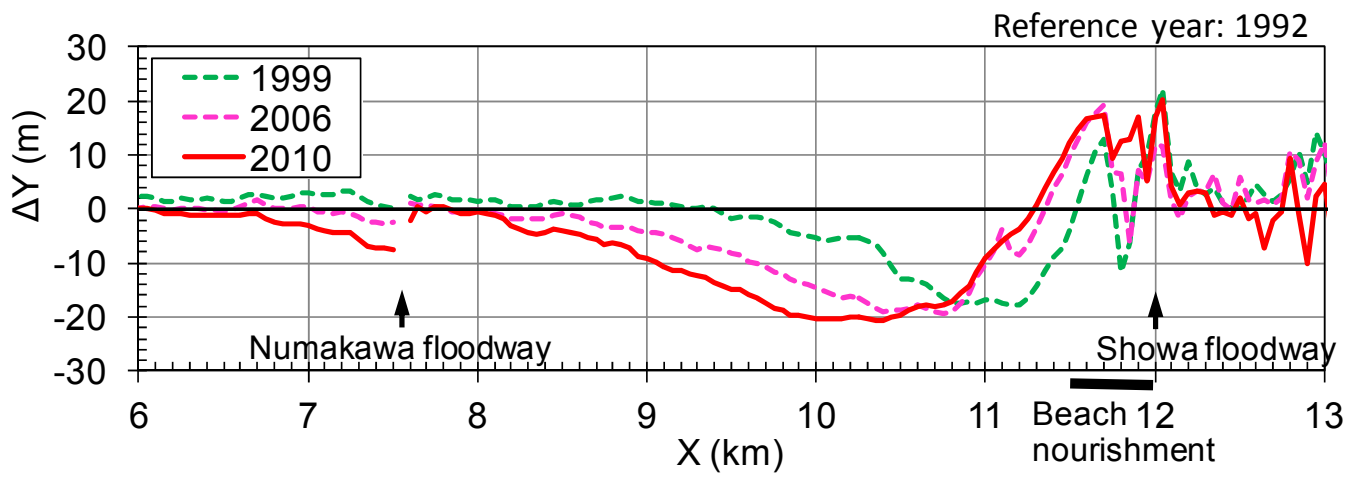

Figure 6. Shoreline changes after beach nourishment with reference to that in 1992.

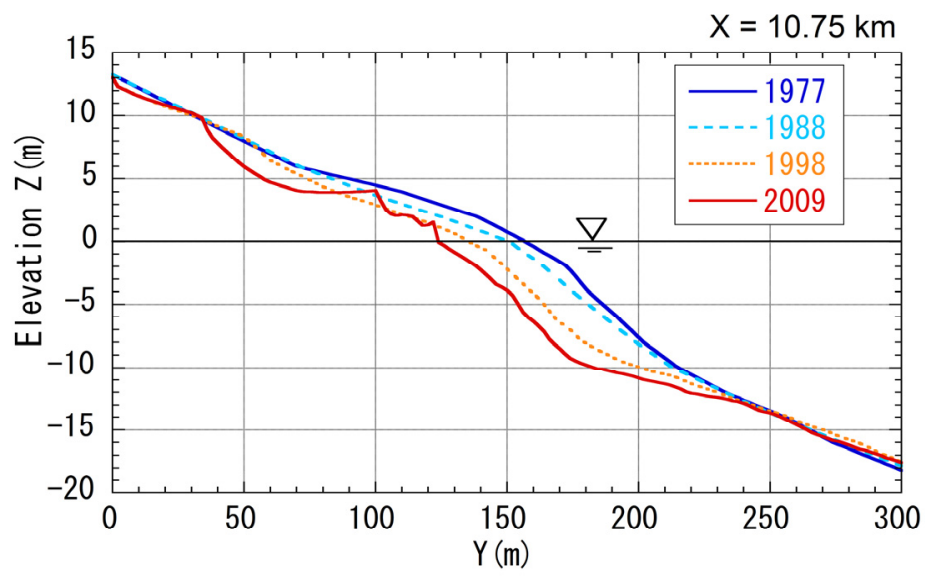

Figure 7. Changes in longitudinal profile downcoast of nourishment area $(X=10.75 \mathrm{~km})$ (provided by Numazu Office of River and National Highway of the Chubu Regional Bureau, MLIT).

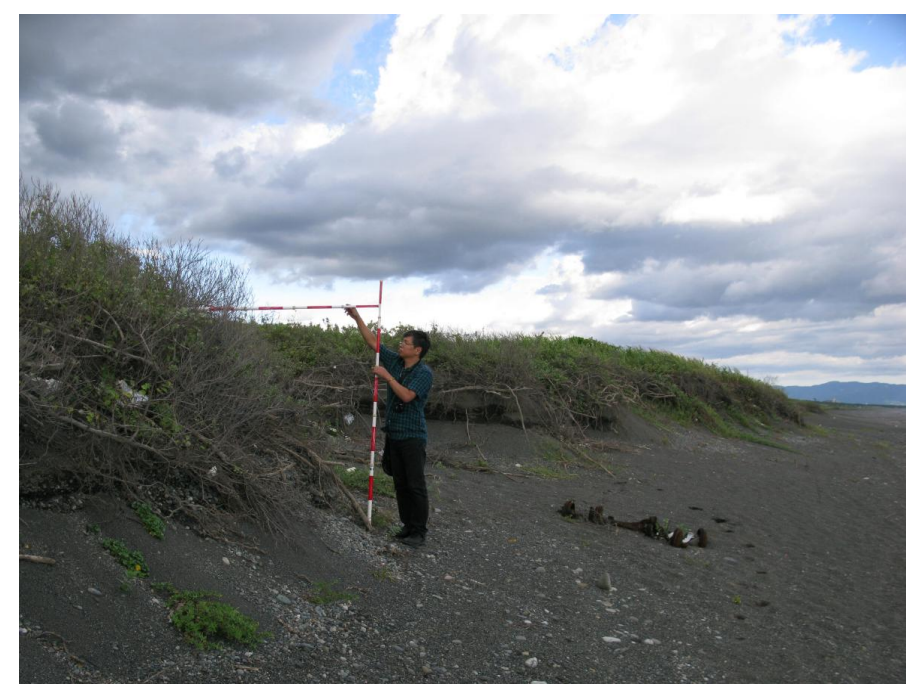

Figure 8. Scarp formation downcoast of nourishment area on Fuji coast.

Figure 9 shows the bathymetry in each year and bathymetric changes after the beach nourishment with reference to that in 1996 measured by a narrow-multibeam survey. A large amount of gravel was deposited, resulting in accretion (red color in Fig. 9) in the nourishment area, whereas beach erosion (blue color) occurred in a widespread area downcoast of the nourishment area. These results clearly 
demonstrate that the selection of grain size for beach nourishment is a key factor in shore protection. If the appropriate grain size of gravel is selected, shore protection may be possible by gradual longshore movement of the gravel body. Thus, we may use this method to control longshore sand transport, and this method using the gradual movement of the gravel body can be called as the Moving Gravel Body method. This method may be one of the adaptive management methods for beach erosion.

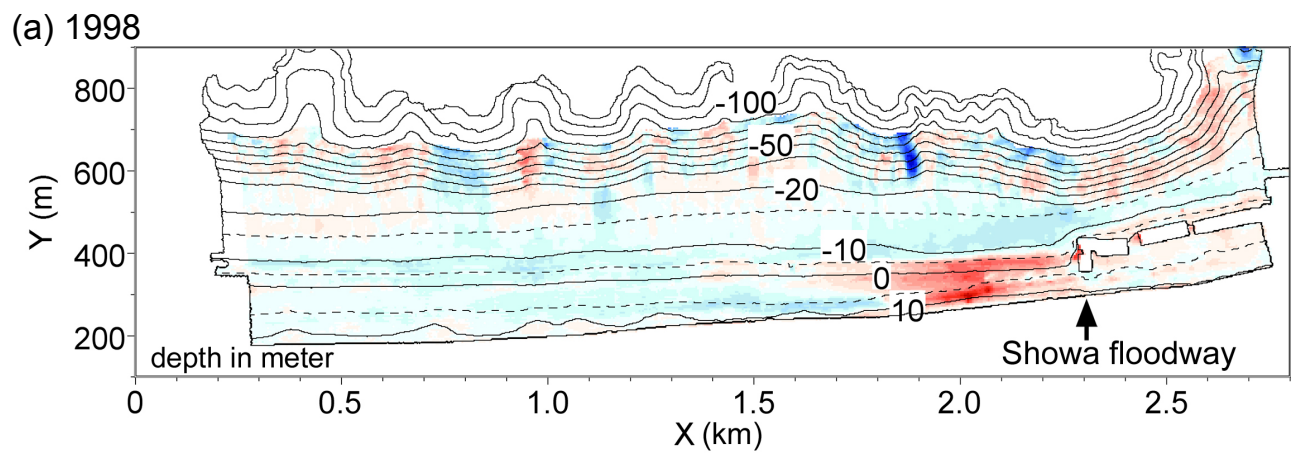

(b) 2002

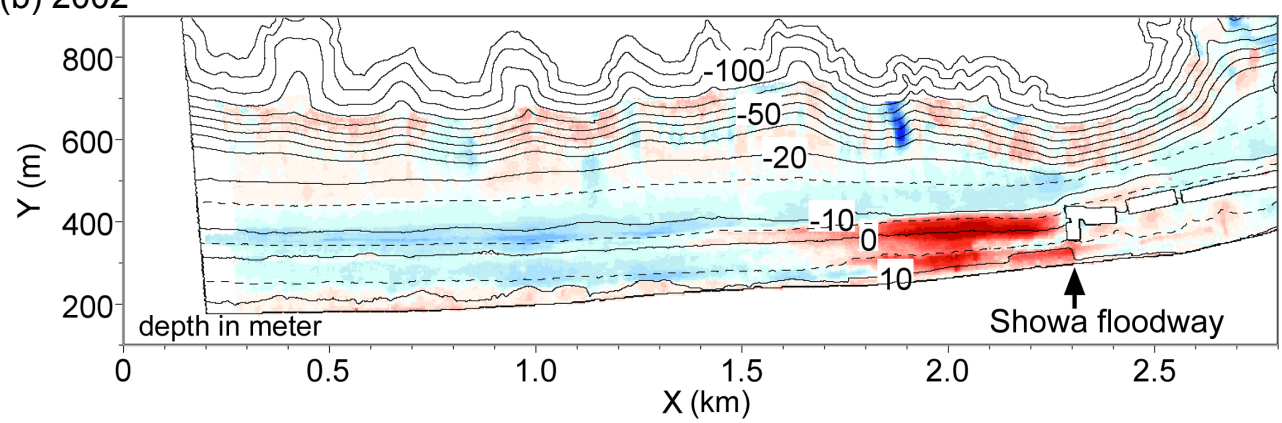

(c) 2006

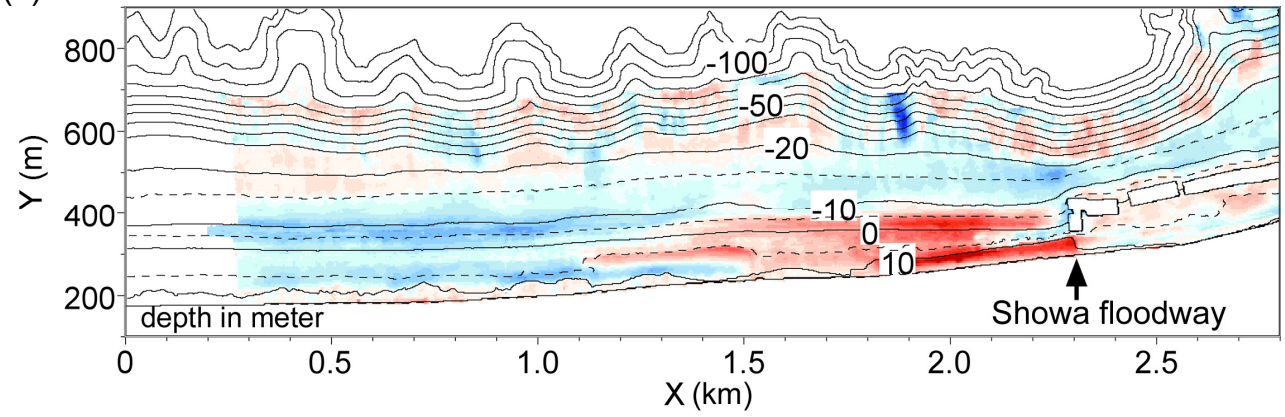

(d) 2010

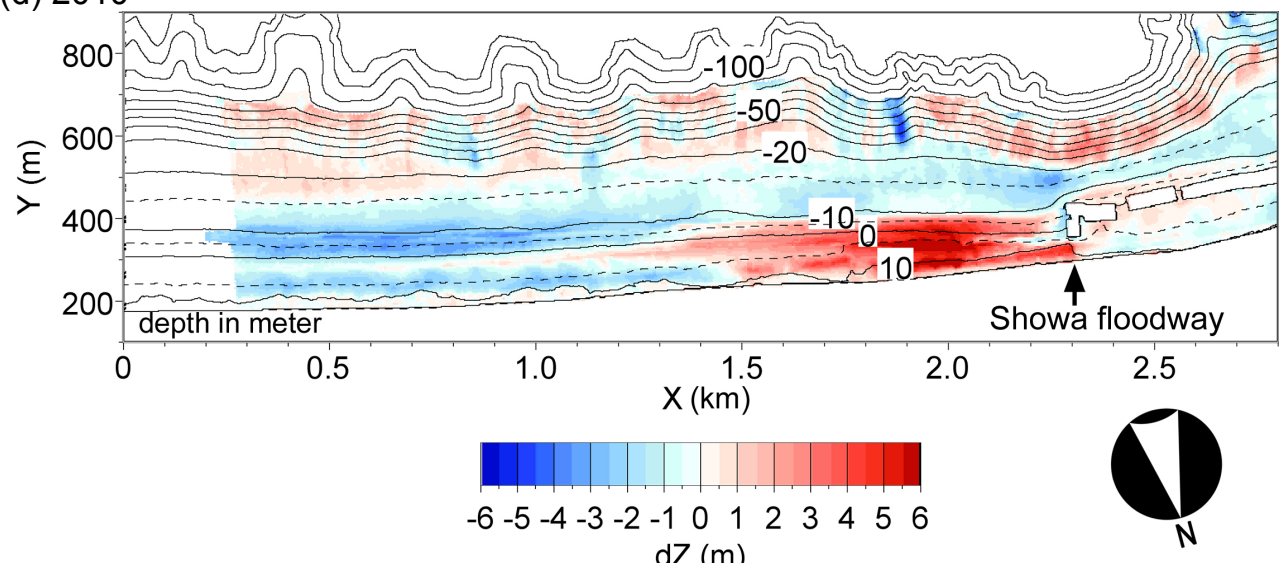

Figure 9. Bathymetric changes after beach nourishment with reference to that in 1996 using narrowmultibeam survey data (provided by Numazu Office of River and National Highway of the Chubu Regional Bureau, MLIT). 


\section{CALCULATION TO STUDY CONCEPT OF MGB METHOD}

\section{Calculation Conditions}

To study the concept of the MGB method, the contour-line-change model considering changes in grain size (Uda and Serizawa, 2010) was used. Consider a dynamic equilibrium condition in which constant longshore sand transport continuously develops before the blockage of leftward longshore sand transport. In this model, the mobility of the bed material is expressed by $1 / V_{d}$, where $d$ is the grain size of sand particles, implying the slower movement of gravel compared with that of fine sand.

We assume that waves with a significant wave height of $H=1.6 \mathrm{~m}$ are obliquely incident with an angle of $10^{\circ}$ from the clockwise direction to the initial shoreline, and leftward longshore sand transport $Q_{0}$ of $1.0 \times 10^{5} \mathrm{~m}^{3} / \mathrm{yr}$ develops. The grain size for the reference is assumed to be $d_{0}=1 \mathrm{~mm}$, which has an equilibrium slope of $\tan \beta_{0}=1 / 10$, and the model beach has a uniform slope of $1 / 10$. Furthermore, the input of longshore sand transport from the right boundary is assumed to be suddenly reduced to 0 .

A free boundary condition was set $\left(d q_{x} / d x=0\right)$ at the left end; a constant longshore sand transport through the boundary developed (Table 1). Figure 10 shows the bathymetry of the dynamic equilibrium beach with a constant leftward longshore sand transport $Q_{0}$ of $1.0 \times 10^{5} \mathrm{~m}^{3} / \mathrm{yr}$. This bathymetry was used as the initial topography.

Then, beach changes after 10 years with no measures and beach nourishment using various grain sizes under the condition that the input of longshore sand transport from the upcoast boundary was reduced to 0 were predicted using this model. In Case 1, beach changes were predicted without any measures. In Cases 2-8, beach nourishment was carried out between $Z=+3$ and $-4 \mathrm{~m}$ in a zone of 200 $\mathrm{m}$ length along the shoreline near the upcoast boundary at a rate of $5 \times 10^{4} \mathrm{~m}^{3} / \mathrm{yr}$, which corresponds to $0.5 Q_{0}$.

Although beach nourishment to produce a beach under the dynamic equilibrium condition and to maintain such a beach must be continued permanently, we assume the condition that such an activity must be inevitably suspended for economic reasons. The equilibrium slope for each grain size of calculation cases was determined on the basis of the field data obtained on the Fuji, Hamamatsushinohara (Ishikawa and Uda, 2011), Shonan (Ishikawa et al., 2009) and Seisho coasts (Serizawa et al., 2009), and the values obtained are shown in Table 2.

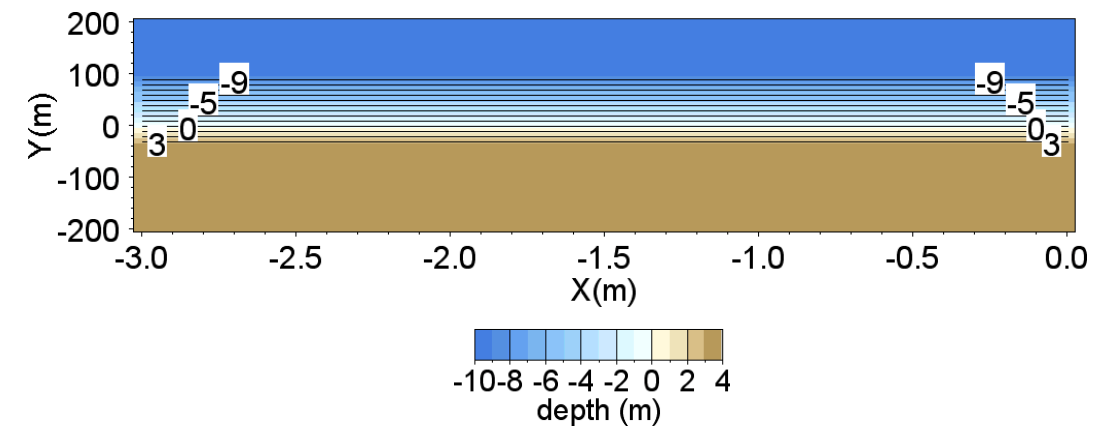

Figure 10. Bathymetry of dynamic equilibrium beach with constant leftward longshore sand transport $Q_{0}$ of $1.0 \times 10^{5} \mathrm{~m}^{3} / \mathrm{yr}$. 


\begin{tabular}{|c|c|}
\hline Numerical model & $\begin{array}{l}\text { Contour-line-change model considering grain size change (Uda and } \\
\text { Serizawa, 2010) }\end{array}$ \\
\hline Calculation domain & Rectangular area of $3 \mathrm{~km}$ length and $0.4 \mathrm{~km}$ width \\
\hline Method & $\begin{array}{l}\text { (1) Reproduction of dynamic equilibrium coast with constant longshore sand } \\
\text { transport rate } Q_{0}=1.0 \times 10^{5} \mathrm{~m}^{3} / \mathrm{yr} \\
\text { (2) Prediction of bathymetric changes with no measures and beach } \\
\text { nourishment using various grain sizes at a rate of } 5 \times 10^{4} \mathrm{~m}^{3} / \mathrm{yr}\end{array}$ \\
\hline Initial bathymetry & $\begin{array}{l}\text { (1) Straight parallel contours } \\
\text { (2) Reproduced bathymetry }\end{array}$ \\
\hline Incident wave conditions & $\begin{array}{l}\text { Deep water wave height } H=1.6 \mathrm{~m} \text { and wave period } T=7 \mathrm{~s} \text { (energy-mean } \\
\text { waves) } \\
\text { Wave angle relative to initial shoreline: } \theta_{w}=-10^{\circ}\end{array}$ \\
\hline Tide condition & M.S.L. $0.0 \mathrm{~m}$ \\
\hline Grain size and equilibrium slope & $\begin{array}{l}\text { Original } d_{0}=1 \mathrm{~mm} \text { with equilibrium slope of } \tan \beta=1 / 10 \\
\text { Cases 2-8: Table } 2\end{array}$ \\
\hline Berm height and depth of closure & $h_{R}=3 \mathrm{~m}$ and $h_{C}=9 \mathrm{~m}$ \\
\hline Depth range of calculation & Between $Z=3 \mathrm{~m}$ and $-9 \mathrm{~m}$ \\
\hline Mesh sizes & $\Delta X=50 \mathrm{~m}$ and $\Delta Z=1 \mathrm{~m}$ \\
\hline Time intervals & $\Delta t=1 \mathrm{hr}$ \\
\hline $\begin{array}{l}\text { Correspondence of real time and } \\
\text { time steps }\end{array}$ & One year: 876 steps \\
\hline Sand transport coefficients & $\begin{array}{l}\text { Coefficient of sand transport } A=0.0255 \text { so that longshore sand transport } \\
\text { rate is } 1.0 \times 10^{5} \mathrm{~m}^{3} / \mathrm{yr} \\
\text { Ozasa and Brampton's coefficient }=1.62 \\
\text { Ratio of coefficient of cross-shore sand transport relative to that of } \\
\text { longshore sand transport } K_{z} / K_{X}=0.15\end{array}$ \\
\hline Depth distribution of sand transport & Cubic equation (Uda and Kawano, 1996) \\
\hline Boundary conditions & $\begin{array}{l}\text { (1) Right boundary: } q_{x}=1.0 \times 10^{5} \mathrm{~m}^{3} / \mathrm{yr} \text {, Left boundary: fixed shoreline as } \\
d q_{x} / d x=0 \text {, landward and seaward ends: } q_{z}=0 \\
\text { (2) } q_{x}=0 \text { at right boundary }\end{array}$ \\
\hline Critical slope of falling sand & $1 / 2$ on land and $1 / 3$ on seabed \\
\hline Nourishment conditions & $\begin{array}{l}\text { Rate of beach nourishment: } Q_{0}=5 \times 10^{4} \mathrm{~m}^{3} / \mathrm{yr} \\
\text { Beach nourishment area: between } X=0 \text { and } 200 \mathrm{~m} \text {, and } Z=3 \text { and }-4 \mathrm{~m}\end{array}$ \\
\hline Numerical method & Explicit finite difference method \\
\hline
\end{tabular}

\begin{tabular}{|c|c|c|}
\hline \multicolumn{3}{|c|}{ Table 2. Grain sizes and equilibrium slopes. } \\
\hline Case & Grain size $d(\mathrm{~mm})$ & Equilibrium slope $\tan \beta$ \\
\hline 1 & \multicolumn{2}{|c|}{ No measure } \\
\hline 2 & $150 d_{0}=150$ & $1 / 3$ \\
\hline 3 & $100 d_{0}=100$ & $1 / 3$ \\
\hline 4 & $50 d_{0}=50$ & $1 / 3$ \\
\hline 5 & $10 d_{0}=10$ & $1 / 3$ \\
\hline 6 & $5 d_{0}=5$ & $1 / 5$ \\
\hline 7 & $2 d_{0}=2$ & $1 / 8$ \\
\hline 8 & $1 d_{0}=1$ & $1 / 10$ \\
\hline
\end{tabular}




\section{Calculation Results}

Figure 11(a) shows the predicted results of beach changes in Case 1 with no measures. Erosion began downcoast of the upcoast boundary because of the disruption of longshore sand transport at the upcoast boundary, resulting in the recession of the entire contours between $+3 \mathrm{~m}$ and $-9 \mathrm{~m}$. Figure 11(b) shows the bathymetric changes with reference to the initial topography. Because the depth distribution of longshore sand transport is given by the cubic equation defined by Uda and Kawano (1996), the most severe erosion occurred near the shoreline. Beach erosion began from the upcoast, and the erosion area extended leftward over time. Figure 12 shows the shoreline changes with a maximum shoreline recession of $125 \mathrm{~m}$ at the upcoast boundary after 10 years. It is clear that when longshore sand transport was disrupted on the dynamic equilibrium beach, the erosion area extended downcoast over time.

(a) Bathymetry
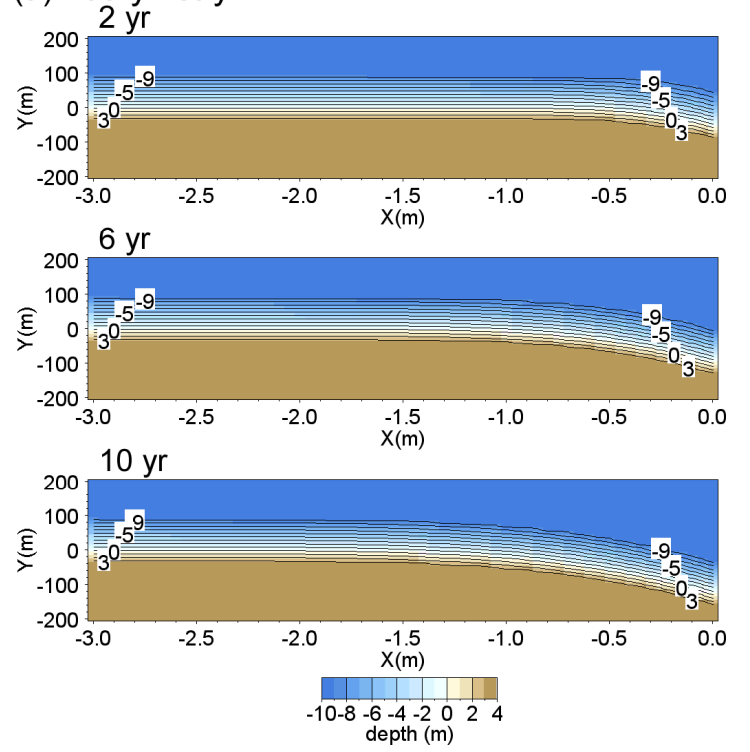

(b) Bathymetric changes
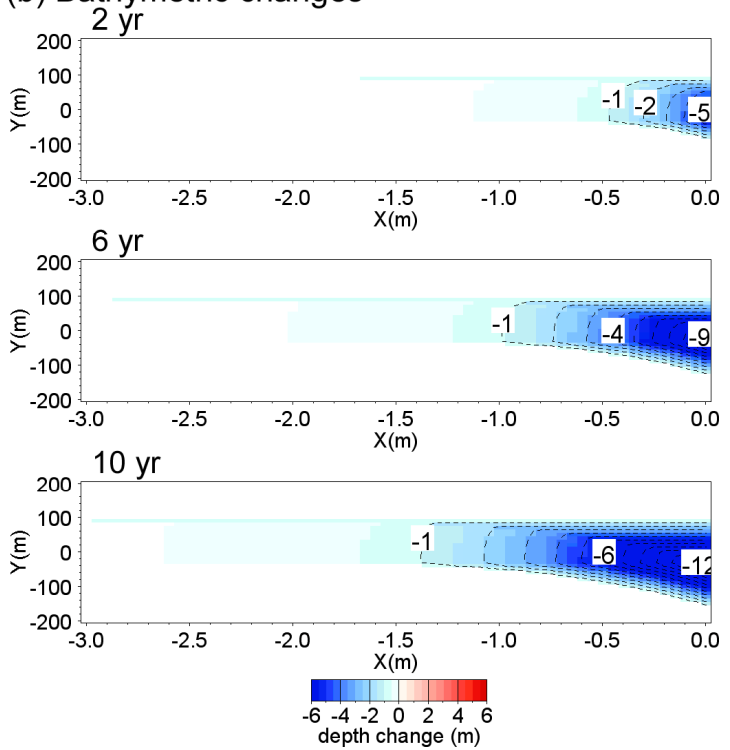

Figure 11. Predicted beach changes after 10 years in Case 1 with no measures.

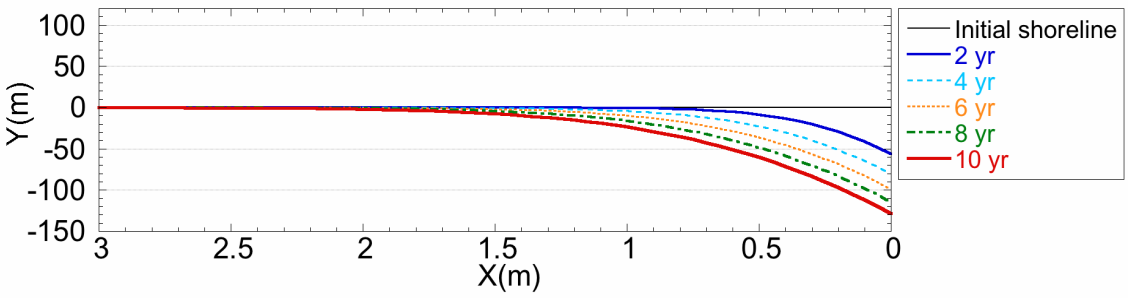

Figure 12. Predicted shoreline changes in Case 1. 
Figure 13 shows the results in Case 2 with beach nourishment using excessively large gravel. The gravel has a grain size 150 times larger than the original grain size. A large amount of gravel was deposited around the nourishment area. In contrast, severe beach erosion was newly triggered downcoast of the nourishment area. The shoreline quickly advanced around the nourishment area with greater grain size, whereas the shoreline severely receded downcoast of the nourishment area over time, as shown in Fig. 14. These numerical results are in good agreement with the results measured on the Fuji coast, as shown in Fig. 6.

When the grain size of the nourishment materials is much larger than that of the original beach materials, erosion downcoast of the nourishment area becomes severe despite beach nourishment, because the movement of the nourishment materials is slower than that of the original materials. Similarly, Fig. 15 shows the shoreline changes in Case 4 with beach nourishment using materials with the grain size 50 times larger than the original grain size. They are similar to the results in Case 2, as shown in Fig. 14.

(a) Bathymetry
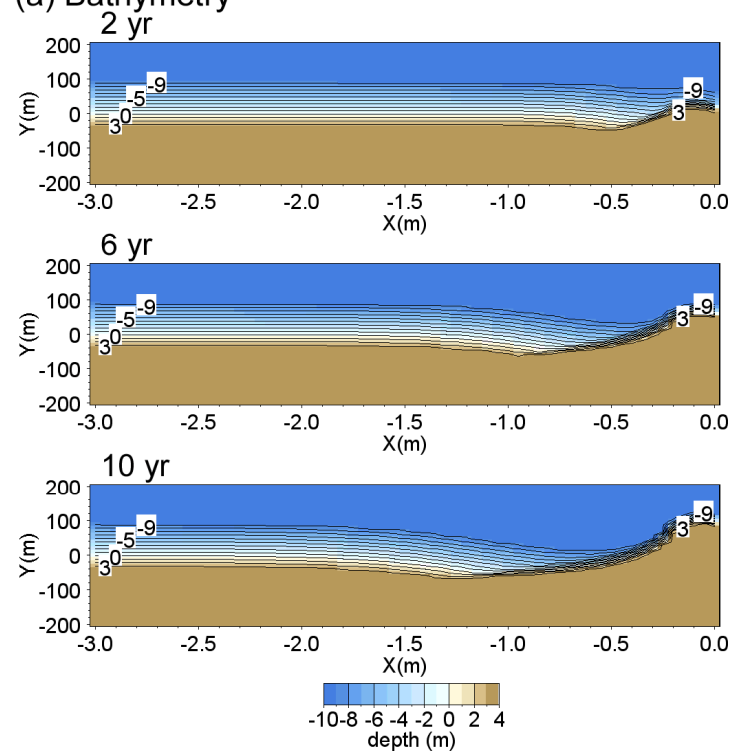

(b) Bathymetric changes
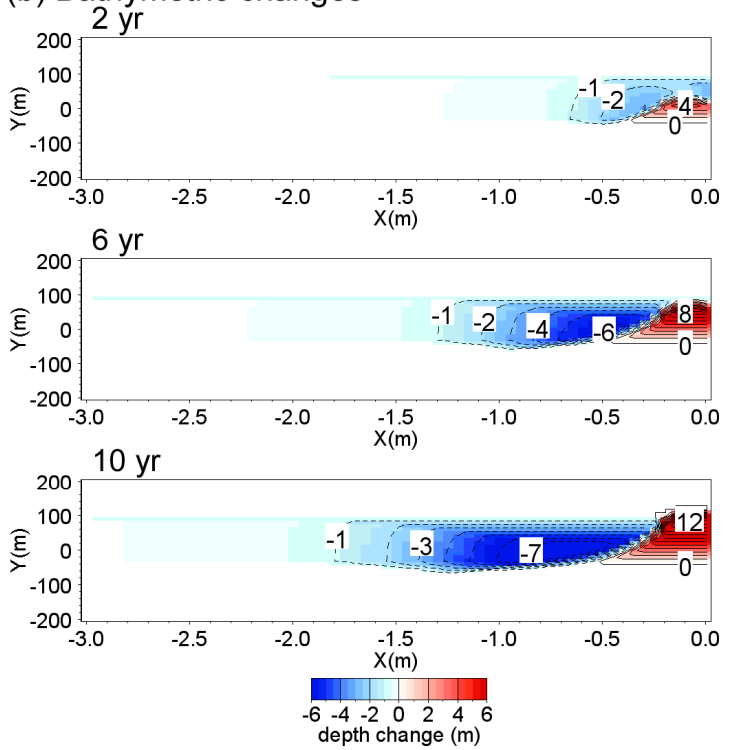

Figure 13. Predicted beach changes after 10 years in Case 2 with beach nourishment using materials with grain size 150 times larger than the original grain size.

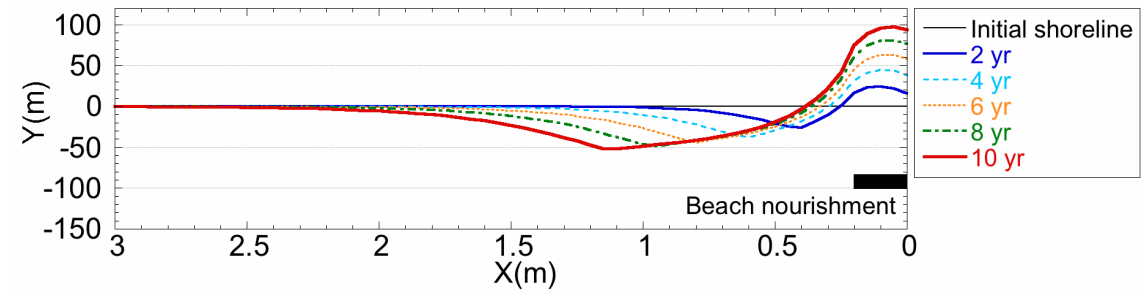

Figure 14. Predicted shoreline changes in Case 2. 


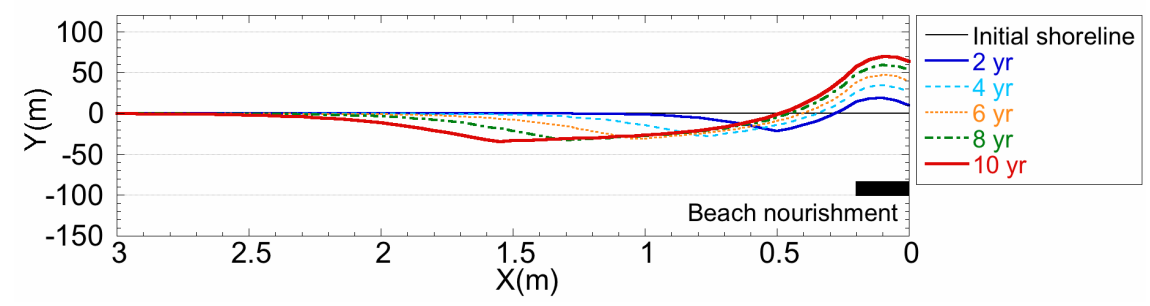

Figure 15. Predicted shoreline changes in Case 4 with beach nourishment using materials with grain size $\mathbf{5 0}$ times larger than the original grain size.

Figure 16 shows the results in Case 5 with beach nourishment using materials with the grain size 10 times larger than the original grain size. The tip of the gravel body gradually extended downcoast over time. This demonstrates the mechanism of the moving gravel body. Also, the beach is almost protected alongshore, as shown in Fig. 17. The slightly large gravel is effective for preventing rapid beach erosion and obtaining a gentle effect for shore protection without severe downcoast erosion.

(a) Bathymetry
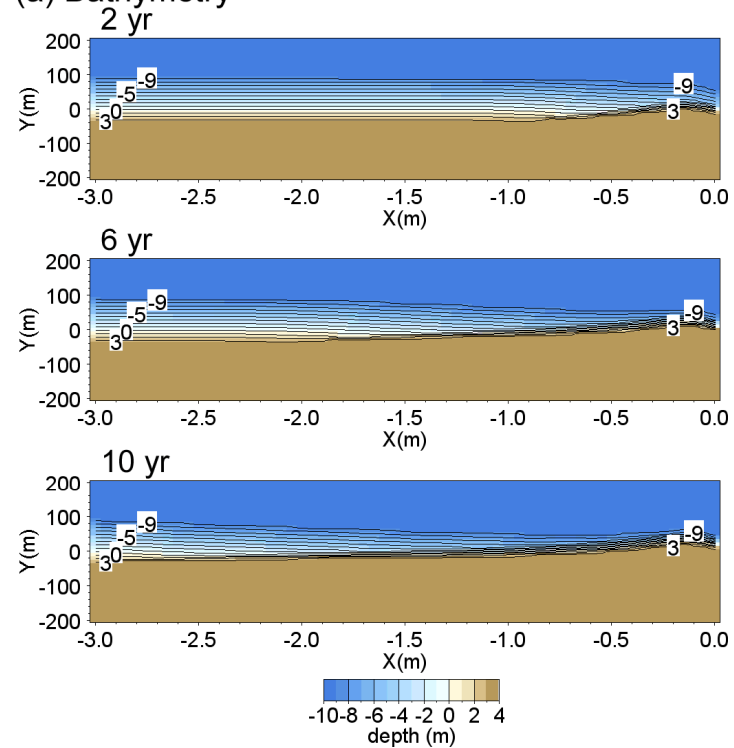

\section{(b) Bathymetric changes}
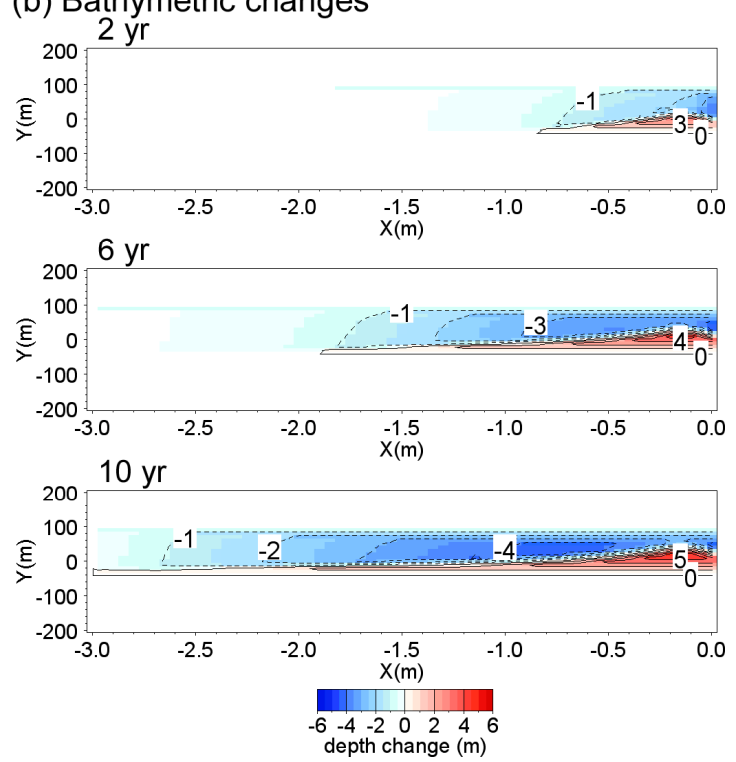

Figure 16. Predicted beach changes after 10 years in Case 5 with beach nourishment using materials with grain size 10 times larger than the original grain size.

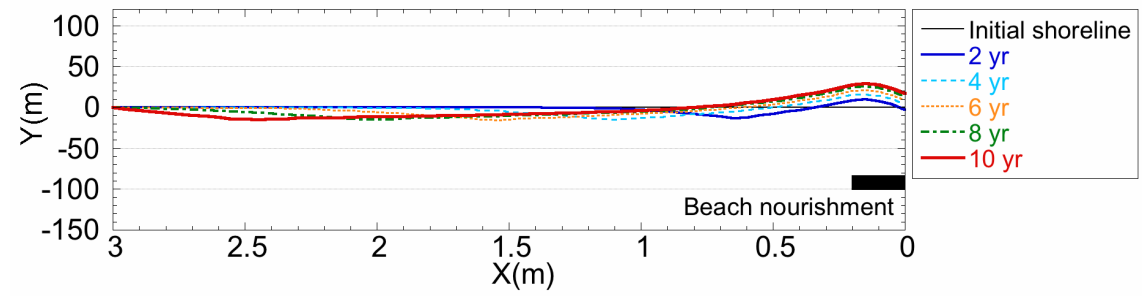

Figure 17. Predicted shoreline changes in Case 5. 
In Case 6 with the grain size 5 times larger than the original grain size, the gravel body more quickly moved downcoast than that in Case 5, as shown in Fig. 18. As a result, the shoreline was completely maintained up to the level of the initial shoreline, as shown in Fig. 19. Finally, Figs. 20 and 21 show the results in Case 7 with beach nourishment using twice the original grain size. The moving gravel body moved very fast downcoast, and therefore the initial shoreline near the upcoast boundary could not be maintained.

When longshore sand transport is disrupted on the dynamic equilibrium beach, the erosion area extends downcoast from the upcoast boundary. If beach nourishment using excessively large gravel was employed as a measure against such erosion, the shoreline in the nourishment area was effectively maintained because the grain size of the nourishment materials was greater than that of the original beach sand. However, severe beach erosion was triggered downcoast of the nourishment area, because the longshore movement of the nourishment material is slower than that of the original material. On the other hand, when beach nourishment using slightly large gravel is carried out, shore protection is possible by the gradual longshore movement of the gravel body. This is the MGB method. In this study, the appropriate grain size in the MGB method is 5-10 times the original grain size.

(a) Bathymetry
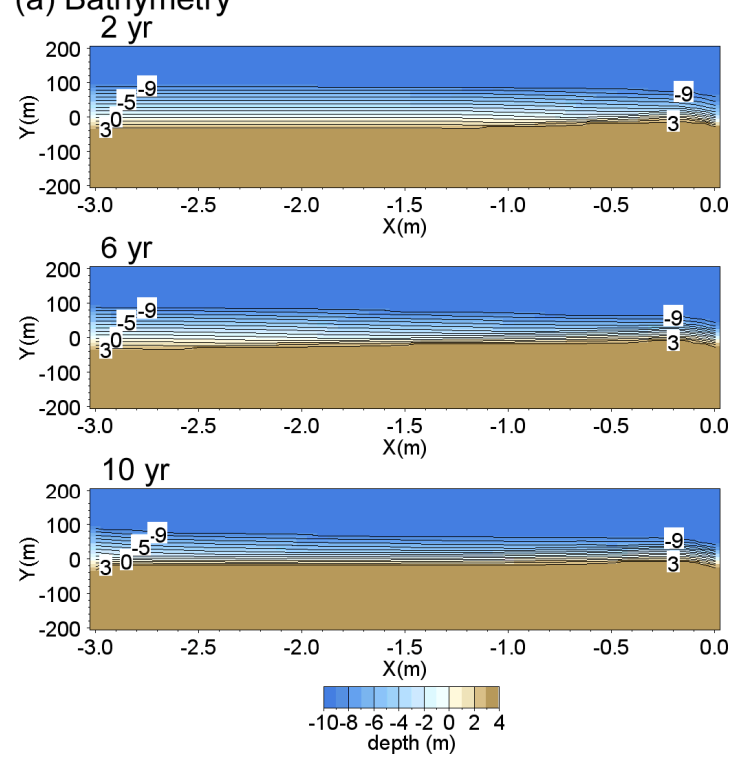

\section{(b) Bathymetric changes}
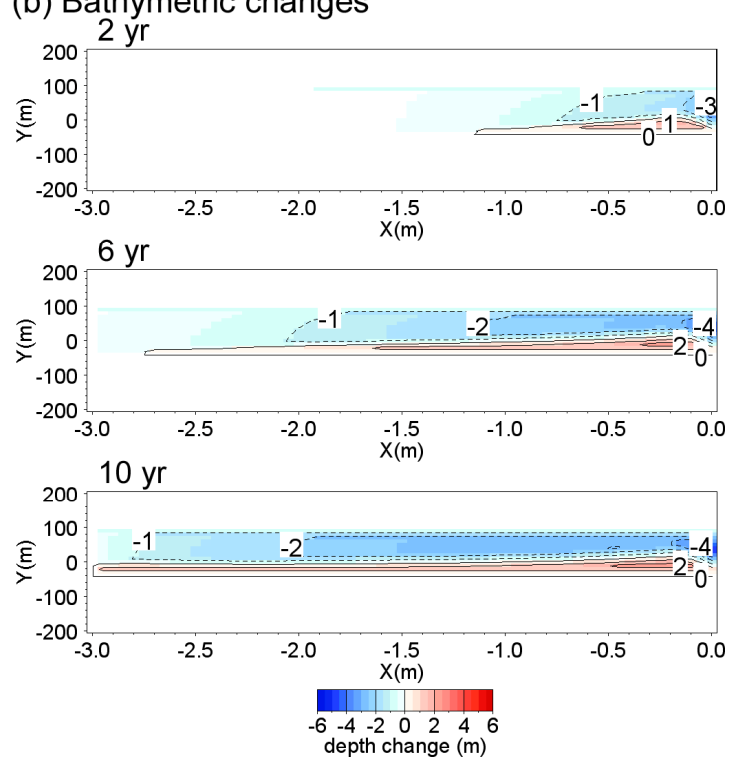

Figure 18. Predicted beach changes after 10 years in Case 6 with beach nourishment using materials with grain size 5 times larger than the original grain size.

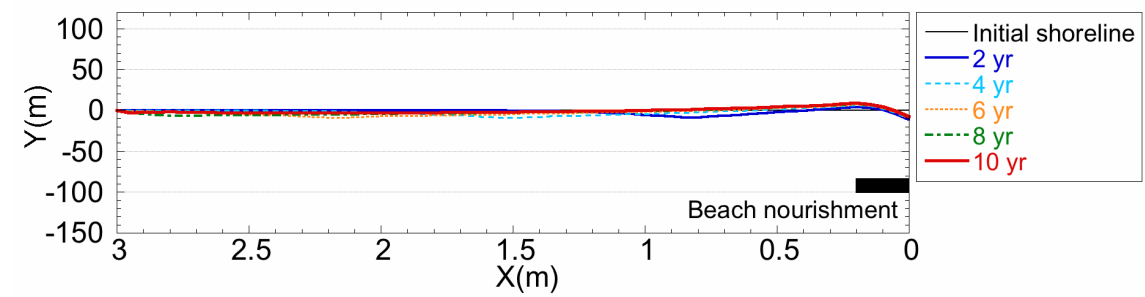

Figure 19. Predicted shoreline changes in Case 6. 
(a) Bathymetry
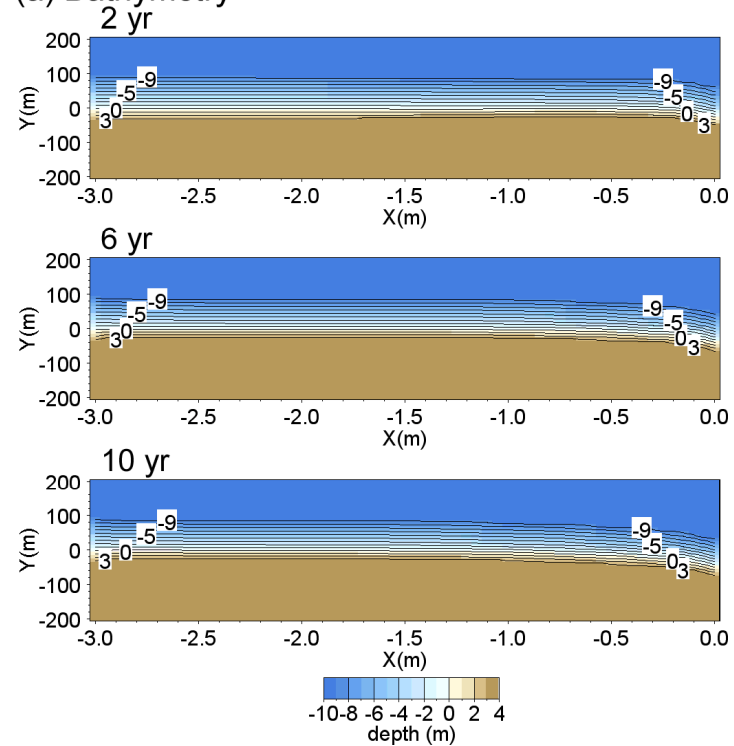

(b) Bathymetric changes
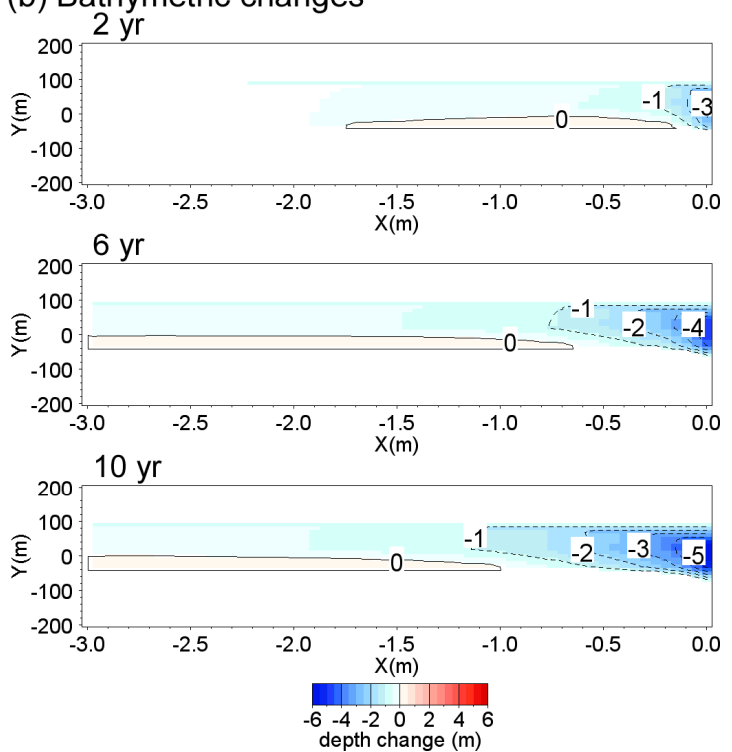

Figure 20. Predicted beach changes after 10 years in Case 7 with beach nourishment using materials with grain size 2 times larger than the original grain size.

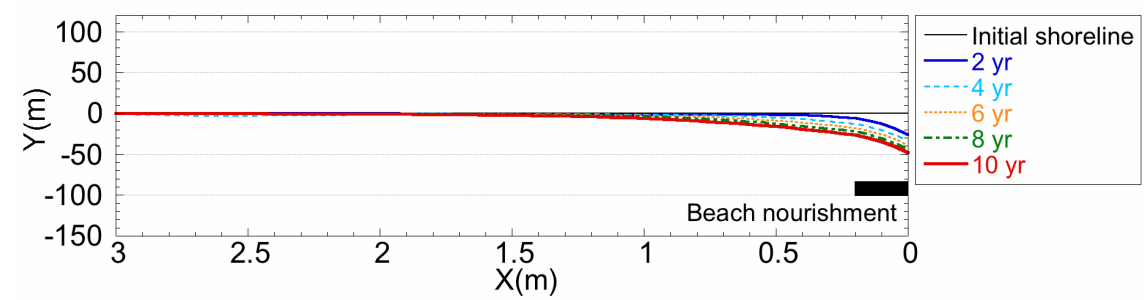

Figure 21. Predicted shoreline changes in Case 7.

\section{DISCUSSION}

Figure 22 shows a summary of the concept of the MGB method. Under the condition that longshore sand transport from upcoast $Q_{\text {in }}$ is smaller than $Q_{\text {out }}$ flowing out of the left boundary, the erosion zone inevitably extends downcoast (Fig. 22(a)). In this case, if sand with the same grain size as the beach materials is supplied to the eroded site via longshore sand transport at a rate of $Q_{\text {out }}-Q_{\text {in }}$, the present shoreline can be theoretically maintained (Fig. 22(b)). However, the procurement of a sufficient volume of those materials is often difficult so that a limited volume of sand of $V_{2}$ is supplied to the beach annually under the condition of a high rate of longshore sand transport, resulting in the further expansion of the erosion zone, although the eroded volume may be reduced compared with that in the case with no measures (Fig. 22(c)).

Consider the case that a limited volume of sand of $V_{2}-V_{1}$ can be used, in which $V_{1}$ and $V_{2}$ are the eroded volume per year and the sand volume to be supplied by the beach nourishment, respectively. When the materials, the grain size of which is less than the original grain size $d_{0}$, are used, the nourishment materials discharge offshore, resulting in beach erosion, the same as in the case with no measures. On the other hand, when $d_{2}$ slightly greater than $d_{0}$ is used, the shoreline in the area to be protected can be maintained, and downcoast beach erosion is prevented (Fig. 22(d)).

Beach nourishment using slightly coarse materials is effective for preventing rapid beach erosion and obtaining a gentle effect for shore protection. However, when $d_{3}$ much greater than $d_{0}$ is adopted, severe downcoast erosion occurs, as well as the deepening of the offshore zone, although the shoreline in the area to be protected advances, because the mobility of the nourishment materials is lower than that of the original beach materials. As a result, a coast vulnerable against wave action is formed. In particular, when excessively coarse materials are used (Fig. 22(e)), the results are similar to that when concrete armor units were placed along the shoreline (Fig. 22(f)). 
These results clearly demonstrate that the grain size that is effective for the recovery and maintenance of the shoreline in the area to be protected and that does not cause downcoast erosion is slightly larger than that of the present beach materials (Fig. 22(d)). This is the fundamental concept of the MGB method. The most appropriate condition for beach nourishment by the MGB method is the use of $d_{2}$, which is 5-10 times greater than the original grain size in this study.

(a) No measure

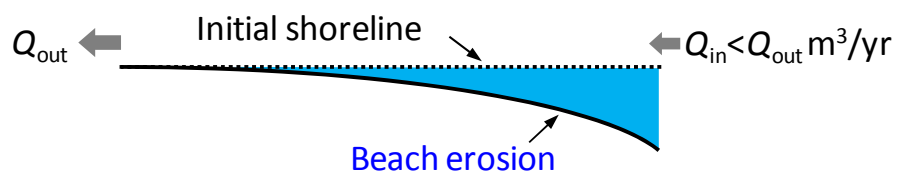

(b) Beach nourishment using same materials $d_{1}=d_{0}$

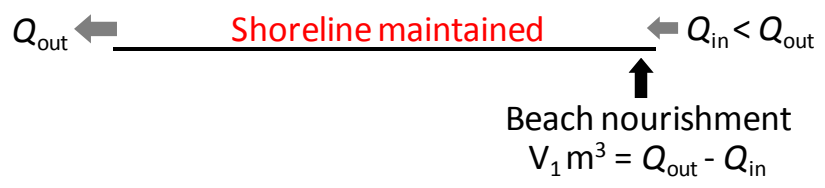

(c) Beach nourishment using same materials $d_{1}=d_{0}, v_{2}<v_{1} m^{3}$

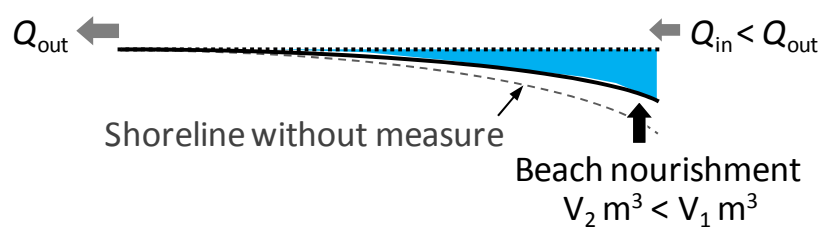

(d) MGB (Beach nourishment using slightly coarse materials $d_{2} \geq d_{0}$ )

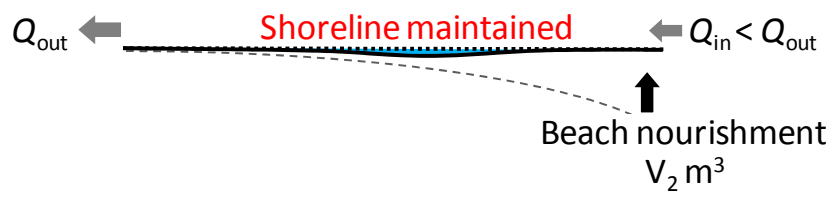

(e) Beach nourishment using excessively coarse materials $d_{3} \gg d_{0}$

Shoreline advanced

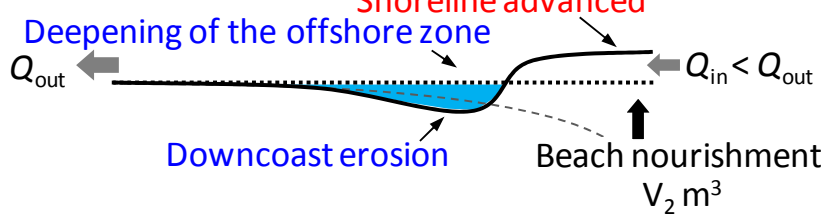

(f) Concrete armor units

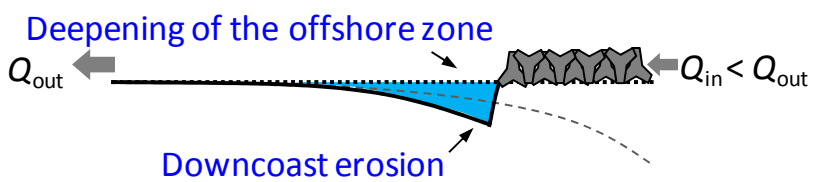

Figure 22. Concept of MGB method. 


\section{CONCLUSION}

Using the analysis of monitoring survey data and the contour-line-change model considering changes in grain size $d_{0}$, the concept of the MGB method was investigated. When materials with a grain size greater than the original grain size were used for the nourishment, the most severely eroded area could be protected compared with that in the case with no measures, but beach erosion will occur immediately downcoast of the nourishment area, if an excessively large grain size is selected, resulting in the downdrift shift of the most severely eroded area. Slightly coarse materials are effective for the recovery and maintenance of the shoreline in the area to be protected without causing further downcoast erosion. The MGB method can be one of the shore protection methods utilizing gradual longshore movement of the gravel body with appropriate grain size on a coast, wherein a predominant longshore sand transport develops. The appropriate grain size is that of the slightly coarse materials $d \geq$ $d_{0}$. This method is predicted to become one of the adaptive management methods when this is reasonably designed. Also, the effect of slightly coarse materials on the coastal environment is assumed to be small compared with that of excessively coarse materials or concrete armor units. Further work, however, is necessary regarding the impacts of the injection of gravels on the sandy beach, such as the effects on the nesting of sea turtles and coastal vegetations.

\section{ACKNOWLEDGEMENT}

This study is a part of the results of the Tenryu-Enshunada Project financially supported by the Japan Science and Technology Agency (JST). We would like to express our gratitude for the support.

\section{REFERENCES}

Ishikawa, T., T. Uda, T. San-nami, G. Aoshima, and A. Yoshioka. 2009. Comprehensive management of sand considering grain size on Shonan coast, Proc. Coastal Dynamics 2009, Paper No. 71, pp. $1-12$.

Ishikawa, T., and T. Uda. 2011. Effect of beach nourishment using gravel and tracking movement of gravel, Proc. $6^{\text {th }}$ APAC 2011, pp. 191-198.

Kumada, T., T. Uda, and T. Ishikawa. 2009. Theory and field test of beach nourishment using coarse sand and gravel, Proc. Coastal Dynamics 2009, Paper No. 75, pp. 1-11.

Kumada, T., T. Uda, T. Matsu-ura, and M. Sumiya. 2010. Field experiment on beach nourishment using gravel at Jinkoji coast, Proc. $32^{\text {nd }}$ ICCE, sediment.100, pp.1-13.

Ozasa, H., and A. H. Brampton. 1980. Model for predicting the shoreline evolution of beaches backed by seawalls, Coastal Eng., Vol. 4, pp. 47-64.

Serizawa, M., T. Uda, K. Suzuki, S. Maruyama, H. Takano, T. San-nami, and T. Ishikawa. 2009. Numerical simulation of rapid erosion of Seisho coast triggered by storm waves during Typhoon 0709, Proc. Coastal Dynamics 2009, Paper No. 93, pp. 1-14.

Uda, T., and S. Kawano. 1996. Development of a predictive model of contour line change due to waves, Proc. JSCE, No. 539/II-35, pp. 121-139. (in Japanese)

Uda, T., and M. Serizawa. 2010. Model for predicting topographic changes on coast composed of sand of mixed grain size and its applications (Chap. 16), pp. 327-358, in 'Numerical simulationsexamples and applications in computational fluid dynamics' Angermann, L. ed., INTEC.

Yoshioka, A., T. Uda, G. Aoshima, K. Furuike, and T. Ishikawa. 2008. Field experiment of beach nourishment considering change in grain size and prediction of beach changes, Proc. $31^{\text {st }}$ ICCE, pp. 2694-2706. 